\title{
Resisting (In)visible Women of Solidarity: Gender in American and Polish Oral History, Life Writing, Visual Arts and Film Part I**
}

Resisting (In)visible Women of Solidarity: Gender in American and Polish Oral History, Life Writing, Visual Arts and Film. Part I. Unlike American historians challenging the marginalization of women since the 1970s and theorizing usefulness of gender for history, the majority of Polish historians have been rather reluctant to address gender differences. The collapse of communism and transatlantic interest in retraditionalization stimulated interdisciplinary engendering of Solidarity. This article examines how significant, though strategically invisible, Solidarity women activists of the 1980s have been represented in oral history, art, and film as well as dialogical genres such as auto/biography and a relational memoir. Questioning of mythical visions of Solidarity, focused on men and class, has initially been resisted, but encouraged a debate about gender stereotypes in Poland. The early "archive fever" followed by a recent surge in transgenerational life writing on women oppositionists exploring gender along with ethnicity, class, and age has helped to construct multi-layered portraits of anti-communist resistance. The analysis of the award-winning documentary, several Solidarity women evaluate critically their complicity with the (post)totalitarian system, may also complicate ultranationalist narratives and fill gaps in postcolonial studies of Central Europe.

Keywords: gender, Solidarity, oral history, life writing, autobiography

* Address: Institute of English Studies IFA, ul. Kuźnicza 22, 50-138 Wrocław. E-mail: elzbieta. klimek-dominiak@uwr.edu.pl.

** The second part of this essay: titled "Daughters and Sons of Solidarity Ask Questions: Resistance, Gender, Race, and Class in Transgenerational Women's Auto/biography, Film and New Media" will be published in the next volume of Miscellanea Posttotalitariana Wratislaviensia. 


\section{1. (In)visibility of women in art and the public discourse about Solidarity resistance}

Several mystifying, blank pages are visible from a distance at the exhibition of the Muzeum Sztuki Nowoczesnej in Warsaw. The work is titled "Invisible Women of Solidarity ( 6 out 5 million)" (2009) and on closer inspection six barely visible, shaded outlines of female portraits emerge from the seemingly empty pages. Next to these (in)visible portraits, short biographical notes based on these women's personal narratives provide information about their involvement in various forms of resistance activities from founding and editing of the leading underground weekly Tygodnik Mazowsze [Mazovian Weekly] and press agency, Agencja Prasowa Solidarność AS, to acting as a member of regional Solidarity boards. Sanja Ivecović, the Croatian artist who is the author of this work, explained that in this art project she focused on remembering the faces and lives of women activists of Solidarity who were erased from Polish collective narratives about the 1980s:

The "Solidarity" trade union in Poland had a large number of female members (c. 5 million); it is thanks to these women that the resistance movement survived through the grim years of martial law in the early 1980s. It was the women who looked after the leaders of the Union while they were in hiding and it was the women who took care of circulating information within the Union... It was the women who devised survival strategies for the opposition and ways of informing society about political events in order to sustain its commitment. However, when democracy took over in Poland, not many of these women were admitted to senior political posts, thus they were not in a position that would have enabled them to influence important political decisions in the country. As a consequence, some key women's rights were lost at this point... Nowadays the vast majority of these brave women, who brought down the Communist regime in Poland, have been wiped from the collective memory ${ }^{1}$.

In another part in this project resisting the symbolic removal of Solidarity women from the public space a decade after the first partially free elections were held in Poland, Ivecović reclaimed Tomasz Sarnecki's iconic 1989 election poster representing Gary Cooper as the sheriff of High Noon wearing a Solidarity badge and holding a ballot instead of a gun and modified the gender of the voter by substituting the male figure with a black silhouette of a woman. This altered poster titled "W samo południe 1989-2009" [High Noon 1989-2009] was published on the cover of Wysokie Obcasy [High Heels, a feminist supplement to Gazeta Wyborcza] and the (in)visible portraits of several Solidarity women were included in the New Left Krytyka Polityczna [The Political Critique] periodical ${ }^{2}$.

Despite its potentially subversive appeal, this transnational artistic intervention marking the 10th anniversary of the Polish (r)evolutionary change in 2009 has not

1 S. Ivecović, "Invisible Women of Solidarity", Revista Arta, 2009, https://revistaartaveche.wordpress.com/2014/10/08/english-invisible-women-solidarity-6-5-million/ (access: 4.05.2016).

2 S. Ivecović, "Invisible Women of Solidarity", "W samo południe 1989-2009” [High Noon 1989-2009] Muzeum Sztuki Nowoczesnej, Warszawa 2009, http://artmuseum.pl/en/kolekcja/praca/ ivekovic-sanja-invisible-women-of-solidarity (access: 4.05.2016). 
affected significantly the Polish master narrative of the mainstream, male-gendered history and public discourse on the Solidarity underground. Thus, Poland celebrated its 25th anniversary of the first partially free elections in the (post)communist countries by organizing predominantly male-centered events with a heavy emphasis on the Polish military alliance with NATO, underscored by the visit of U.S. President, Barack Obama, in Warsaw at the time of the Russian-Ukrainian crisis. The official celebrations also highlighted the benefits of Poland's political independence from Russia, the advantages of European Union membership, transformation to a neoliberal market economy and resisted critiques concerning unequal distribution of these benefits among social classes as well as genders ${ }^{3}$. Ironically, the celebrated Polish EU membership has not yet changed the deeply ingrained suspicion of one of its major policies such as gender equality, or Gender Mainstreaming, in the Polish public discourse and social practice ${ }^{4}$. For example, in the special 25th anniversary edition of Gazeta Wyborcza, bearing the symbolic name "Election Gazette", commemorating its contribution to the historic elections of 1989, which had been possible largely due to its forerunner, Tygodnik Mazowsze founded by underground women activists, Wyborcza's editor-in-chief, formerly imprisoned dissident, Adam Michnik, and the remaining all-male journalists and press photographers involved in this publication reviewed the influential role of the independent press in both the underground and post-communist period by focusing primarily on men's contributions, achievements, and challenges. Women's vital role not only in the underground publishing and transformation of the 1980 Gdańsk bread-and-butter strike into the Solidarity strike, but also during the transition period was apparently forgotten or not worth representing in this significant post-totalitarian cultural narrative ${ }^{5}$.

Yet, these were the Solidarity women who founded both the samizdat underground weekly, Tygodnik Mazowsze, the predecessor of Gazeta Wyborcza, when the numerous male leaders were imprisoned, interned or otherwise isolated and often dependent on women activists, as they had to remain invisible to avoid arrests during martial law. Significantly, preparations for a new underground publication, Tygodnik Mazowsze, were interrupted when its appointed editor-in-chief, Jerzy Zieliński,

3 E.g. D. Ost, The Defeat of Solidarity: Anger and Politics in Postcommunist Europe, Ithaca 2005; and E. Matynia, "Women after Communism: Bitter Freedom", Social Research 61, 1994, no. 2, pp. 351-377 about e.g., high unemployment among former shipyard, coalmine, factory workers and young people, feminization of poverty, and restrictions of women's reproductive rights.

4 Compare: E. Klimek-Dominiak, "Gender Mainstreaming po polsku" [Gender Mainstreaming in Polish], Zadra. Pismo feministyczne 66-67, 2016, no. 1-2, pp. 54-57; and A. Gerber, "The Letter Versus the Spirit: Barriers to Meaningful Implementation of Gender Equality Policy in Poland", Women's Studies International Forum 2010, no. 33, pp. 30-37.

${ }^{5}$ Gazeta na urodziny [Birthday Newspaper], Gazeta Wyborcza 8.05.2014; and P. Pacewicz, "25 lat Wyborczej. Kobiety się nie załapały" [25 Years of Gazeta Wyborcza. Women Didn’t Make It], Dziennik Opinii. Krytyka Polityczna 14.05.2014, http://www.krytykapolityczna.pl/artykuly/opinie/20140514/ pacewicz-25-lat-wyborczej-kobiety-sie-nie-zalapaly (access: 4.05.2016). 
committed suicide ${ }^{6}$ on December 13, 1981, before the first issue of this weekly was assembled. Importantly, since martial law drastically limited civil liberties and communication by delegalizing all non-communist, independent organizations, introducing a curfew as well as media and postal censorship, access to non-government information in the pre-internet era was crucial also for the revival of the Solidarity network after this serious blow. As a British historian, Timothy Garton Ash, and an American researcher, Shana Penn, argued persuasively, this major underground publication, edited initially by the experienced, women-only team, was decisive for the success of the first media-based revolution (or "telerevolution") in the Warsaw Pact countries ${ }^{7}$. Similarly, Padraic Kenney, an American historian, and the author of subsequent publications on this subject, "The Gender of Resistance in Communist Poland" (1999) and A Carnival of a Revolution: Central Europe 1989 (2003), confirmed that "women... were absolutely central to the story of Solidarity's triumph in 1989" because "the group of women who created Tygodnik Mazowsze, Solidarity's flagship underground paper, while also coordinating safehouses and distribution networks upon which (male) leadership relied, deserves much credit for this transformation ... [reinventing Solidarity as an underground movement during martial law and surviving until the peaceful transition of '89]" 8 . He also clarified the key importance of this major illegal publication for the non-violent "patient revolution": "Solidarity did not effect the fall of communism through direct confrontation. Though strikes in 1980 and in 1988 and demonstrations were essential to this struggle, in large part, it did so through survival ... Solidarity could weather the sticks and carrots of normalization. It did so through flexibility and communication" ${ }^{\prime \prime}$. Finally, Kenney underscored the importance of both this underground weekly and its originally all-female editors, supporting it with the impressive statistical data about its circulation: "The women of Tygodnik Mazowsze really contributed something new, as they created, wrote, edited, and distributed what must have been the largest underground newspaper ever. (Again those superlatives - but can any other clandestine movement boast press runs of up to 10 000-50 000 every week?)"10.

In the same review of Penn's ground-breaking 1994 research, Kenney recognized the importance of both her central focus on these underground women activists, who according to him as well, "were absolutely central to the story of Solidarity's triumph in 1989", acknowledged the pioneering status of her research as "no

6 “Tygodnik Mazowsze", [in:] Encyklopedia Solidarności, http://www.encysol.pl/wiki/\%E2\%80\%9ETygodnik_Mazowsze\%E2\%80\%9D- (access: 31.08.2016).

7 T. Garton Ash, The Polish Revolution, London 1983, p. 285; and S. Penn, "National Secret", Journal of Women's History 5, 1994, no. 3, p. 55; eadem, Solidarity's Secret: The Women Who Defeated Communism in Poland, Ann Arbor 2005, pp. 4, 51.

8 P. Kenney, "Review of Penn, S. Solidarity's Secret: The Women Who Defeated Communism in Poland”, Habsburg, H-Net Reviews, October 2007, https://www.h-net.org/reviews/showpdf.php?id=13690 (access: 16.11.2015).

9 Ibid.

10 Ibid. 
one else has tackled this story, from a feminist perspective or any other"11. Moreover, Kenney developed implications from her insights in one of the few male-authored publications on the role of gender in Polish anti-communist activism. His article "The Gender of Resistance in Communist Poland" (1999) convincingly supported the thesis that in a largely ethnically homogeneous, post-war Polish society, the gender division played an important role both in the communist regime and in the underground opposition ${ }^{12}$.

In addition, Penn's ground-breaking research demonstrated that many of these skilled underground women publishers, editors and journalists, especially their remarkably talented unofficial manager, Helena Łuczywo, later joined the staff of Gazeta Wyborcza and became also instrumental in the success of this major, legal, post-communist Polish newspaper. Yet, they rarely received public credit for their anonymous work because of their gendered tactics of strategic invisibility, which ensured their success during the resistance movement, as well as pervasive Polish gender stereotypes of modest, supportive, and selfless women patriots, avoiding any suggestions of interdependence of the male freedom-fighters on women activists ${ }^{13}$.

Not only American and British scholars and journalists specializing in Eastern and Central Europe asserted the importance of Tygodnik Mazowsze in reorganizing the underground network of Solidarity's resistance for its survival during seven years of repressions. One of the leading women activists and editors in Warsaw resistance, Ewa Kulik in an interview with John Feffer about "Solidarity Underground" (2015) also underscored the significance of independent information and underground press in the communist regime: "Whoever has information has power...We needed to break the monopoly of the Communist propaganda"14. She also explained the expectations of readers and foreign journalists: "what people really needed was information. So, first of all, we needed to collect information - who was arrested, what plants were on strike, where were other protests - and smuggle it abroad so that it would come back to Poland"15. Additionally, she also highlighted the indispensable function of underground publishing in the reestablishment of clandestine networks after the shock of martial law:

Then we had to produce the papers and the books and distribute them. We had to put together a whole network identifying printing machines that had not been confiscated, finding people who could operate them, organizing the distribution network. We needed to make contact with people who

11 Ibid.

12 P. Kenney, “The Gender of Resistance in Communist Poland", The American Historical Review 104, no. 2, Apr. 1999, p. 400.

13 S. Penn, Solidarity's Secret, pp. 13-14 and the chapter "'Our Romantic Model': Myth, Literature and Woman's Place”, pp. 241-261. See also M. Janion, Kobiety i duch inności [Women and the Spirit of Otherness], Warszawa 1996, pp. 78-101; and S. Walczewska, Damy, rycerze ifeministki [Ladies, Knights, and Feminists], Kraków 1999, pp. 53-56.

14 J. Feffer, "Solidarity Underground", Huffington Post, The World Post 4.07.2015, http://www. huffingtonpost.com/john-feffer/solidarity-underground_b_7019818.html- (access: 5.07.2015).

15 Ibid. 
could enter the plants and those who were not arrested and could organize underground structures. We did all these things in the first few weeks, and it was expanding and expanding ${ }^{16}$.

Several other women oppositionists, such as Barbara Labuda and Małgorzata Tarasiewicz also recognized the importance of uncensored publications and women's accomplishment in rebuilding the Solidarity underground ${ }^{17}$.

Similarly, the major male oppositionist and the chairman of Warsaw Solidarity, Zbigniew Bujak, confirmed the primary importance of the first issue of Tygodnik Mazowsze for the re-establishment of underground cooperation after the "outbreak of 'war"' [martial law] in his 1984 interview for Konspira: Rzecz o podziemnej „Solidarności" [Consipracy: About Underground Solidarity] $(1984,1999)^{18}$. In addition, two other key male oppositionists of this underground oral history, published in Paris at the time of anti-communist resistance, validated the importance of women's activism in the underground Solidarity. Their Konspira is a rare example of a male-authored narrative expressing grief about the lack of appreciation for women's involvement in the underground as "anonymous heroines": "There is not one woman among the signatories of declarations, communiqués, and appeals. Women in the underground are more amenable and less demanding than men. But the participation of women is significant... women are more eager to take up activity than men... They don't have great personal ambitions, and they don't have to be part of the center"19. Władysław Frasyniuk, the main male oppositionist of the Wrocław region, also admitted that gendered differences were generally noticeable in resistance: "Men, on the other hand, are more ambitious (in the negative sense), they like doing more spectacular things, making decisions, being important. If they are asked to carry a (secret) letter, ok, but it must be for Bujak or Frasyniuk, otherwise no"20. Such testimonies of these key male eye-witness participants destabilize other subsequent post-1989,

16 Ibid.

17 S. Penn, Solidarity's Secret, pp. 180-185.

18 M. Łopiński, M. Moskit, M. Wilk, Konspira: Rzecz o podziemnej „Solidarności” [Conspiracy: Underground Solidarity], Gdańsk and Warszawa 1989 (First Edition, Paris 1984).

19 "Wśród sygnatariuszy oświadczeń, komunikatów, apeli, wezwań nie ma bowiem ani jednej osoby płci żeńskiej. A przecież udział kobiet jest znaczący, może nawet - co potwierdza Borusewicz - chętniej podejmują działalność niż mężczyźni... Kobiety w konspiracji są bardziej dyspozycyjne od mężczyzn i mniej wymagające. Nie mają wybujałych ambicji osobistych”. B. Borusewicz [in:] Konspira..., pp. 132, 186. S. Penn, Solidarity's Secret, pp. 219-220.

20 "Mężczyźni natomiast okazują więcej ambicji (w negatywnym sensie), lubią robić rzeczy spektakularne, decydować, być ważni. Jeśli przenoszą list to okej, lecz do Bujaka albo Frasyniuka, inaczej nie”. M. Łopiński, M. Moskit, M. Wilk, op. cit., p. 186. 
grand narratives of predominantly male ${ }^{21}$ contributions to the Polish anti-communist resistance ${ }^{22}$.

Importantly, in addition to Penn, also Józef Pinior, one of the central male underground Solidarity activists in Wrocław, famous for his role in saving Solidarity's 80 millions from confiscation just before martial law, identified the drawbacks of women's strategy of resisting visibility by invoking the case of Danuta Winiarska [since 1990 - Danuta Kuroń]. She successfully organized the underground Solidarity network in the Lublin region during martial law and cooperated with Tygodnik Mazowsze. Since she believed no one would accept a woman leader of resistance in this rather patriarchal, rural region, she invented a fake male leader, "Abramczyk", to represent her "in public". Ironically, when after a year she asked a male acquaintance to "assume Abramczyk's persona ... who followed her instructions", "this man had identified with his role so closely ... that he had forgotten the real story" and in his post-1989 interviews only acknowledged that Winiarska invented his pseudonym ${ }^{23}$. Another representative example of the largely unrecognized roles of many other underground Solidarity women, is Penn's analysis of Barbara Labuda's testimony about her numerous anonymous contributions to the underground male "working-class champion," Władysław Frasyniuk, for whom she had written speeches and was interviewed (e.g., for the Washington Post) in his name, but her part remained largely (in)visible after the post-1989 conservative revolution ${ }^{24}$.

\section{Resistance to gender in a Polish "Ministry of Memory" 25}

Such editorial omissions as in the anniversary issue of Gazeta Wyborcza are symbolic of a more widespread resistance to women's history and gender history not only in the leading Polish newspapers, but also in mainstream Polish history, frequently disregarding archival documents, oral history projects, life writing combined with

${ }^{21}$ J. Kaczyński, Porozumienie przeciw monowładzy. Z dziejów PC [Agreement Against Power Monopoly: Of PC History], Poznań 2016. M. Sutowski, "Kaczyński w opozycji: Ani aktywista, ani publicysta - czyli kto?”. Interview with A. Friszke, Dziennik Opinii, Krytyka Polityczna, 10.08.2016, http://m.krytykapolityczna.pl/artykuly/kraj/20160810/kaczynski-w-opozycji-ani-aktywista-ani-publicysta-czyli-kto- (access 11.08.2016). Compare: A. Friszke, Rewolucja Solidarności 1980-1981, Kraków 2014, about women's role in Solidarity e.g. role of Ewa Kulik (e.g. in Niezależność [Independence]) and about Ewa Milewicz, Barbara Labuda, Danuta Stolecka, Ludwika Wujec.

22 J. Kaczyński's autobiography rarely mentions women's significance in the underground (in passing references) under $10 \%$ of all names are female names.

${ }^{23}$ S. Penn, "National Secret", pp. 55, 62-64. J. Pinior, "Dlaczego Solidarność nie jest już sexy?" [Why Solidarity is no longer sexy?], Dziennik Opinii, Krytyka Polityczna, 4.10.2013, http://www. krytykapolityczna.pl/artykuly/opinie/20131004/pinior-dlaczego-solidarnosc-nie-jest-sexy (access: 30.10.2013).

24 S. Penn, "National Secret", p. 62. Both cases confirmed also by J. Pinior, op. cit.

25 D. Stola, "Poland's Institute of National Remembrance: A Ministry of Memory?", [in:] The Convolutions of Historical Politics, ed. A. Miller, M. Lipman, Budapest 2012, p. 54. 
documentary footage and visual arts, which testify to women's active, inventive, highrisk participation contributing significantly to the anti-communist underground and reflect a relative (in)visibility of such women activists in the textbooks and the dominant cultural narrative about the $1980 \mathrm{~s}^{26}$. One of the few notable exceptions to this practice seems to be promised by the topical title of the recent collected volume, Płeć buntu. Kobiety w oporze spolecznym i opozycji w Polsce w latach 1944-1989 na tle porównawczym [Gender of Rebellion. Women in Civil Resistance and Opposition in 1944-1989 in a Comparative Perspective] (2014). However, since it is edited by Natalia Jarska and Jan Olaszek, both employees of the Biuro Edukacji Publicznej [Office of Public Education], a part of the Instytut Pamięci Narodowej (IPN) [the Institute of National Remembrance] which as a government-affiliated institution combining the functions of a former secret archive with lustration and prosecution powers is often believed to be insufficiently independent of current party "historical politics", it cannot be treated as an entirely reliable academic source ${ }^{27}$. The members of the IPN staff were not only involved in editing of the volume, but many of them also contributed essays ${ }^{28}$.

For example, it is difficult to see the academic merit in one of the texts by Olaszek. In particular, one of his unfounded conclusions about "Rola kobiet w warszawskim podziemiu lat osiemdziesiątych" [The Role of Women in the Warsaw Underground of the 1980s] that "ilościowo dominowali w niej [Solidarności] mężczyźni (choć w ruchu nieformalnym, z płynnymi granicami trudno to jednoznacznie stwierdzić..." [quantitatively, men dominated in Solidarity (although it is difficult to unmistakably estimate it in the informal movement with fluid boundaries)] is an example of flawed logic ${ }^{29}$. Moreover, in the description of his research methodology, Olaszek states that he used files of the Secret Service [which are incomplete and otherwise unreliable, because they were not produced in order to document history], as well as popular and academic sources, which he did not support with

${ }^{26}$ I. Chmura-Rutkowska, E. Głowacka-Sobiech, I. Skórzyńska, “'Niegodne historii'. O nieobecności kobiet w dziejach w kontekście analiz wybranych podręczników do nauki historii w Polsce" [Unworthy of History. Absence of Women in Historiography in the Analysis of the Selected History Textbooks in Poland], Sensus Historiae XII, 2013, no. 4, pp. 47-70. A. Janiak-Jasińska, K. Sierrakowska, "Historiografia" [Historiography], [in:] Encyklopedia Gender: Płeć w Kulturze [Encyclopedia of Gender: Gender in Culture], ed. M. Rudaś-Grodzka et al., Warszawa 2015, pp. 191-194.

27 D. Stola, op. cit., p. 55.

${ }^{28}$ However, a few non-IPN affiliated authors also contributed essays in Płeć Buntu... For example, M. Fidelis’s "Przodownice pracy i buntowniczki: strajki kobiet w Żyrardowie" (1945-1951), A. Leszczyński's “'Kobitki gołą dupę mu pokazywały. Gender i protest włókniarek w Żyrardowie (listopad $1981 \mathrm{roku}$ )" or S. Penn’s "Analiza porównawcza działalności kobiet w czechosłowackich i polskich ruchach opozycji antykomunistycznej w latach 1968-1989" come from academic researchers, independent scholars or visiting professors and report original data and convincing comparative analysis of gender in women's resistance.

29 J. Olaszek, "Rola kobiet w warszawskim podziemiu lat osiemdziesiątych", [in:] Płeć buntu. Kobiety w oporze społecznym i opozycji w Polsce w latach 1944-1989 na tle porównawczym, ed. N. Jarska, J. Olaszek, Warszawa, 2014, p. 306. 
statistical data ${ }^{30}$. In addition to these vague statements, he undervalues the examples concerning non-traditional women's gender roles in opposition, while highlighting those which focused on traditionally "female" occupations such as "less visible and spectacular domains" 31 of supportive work and care for the family and community. Olaszek suggests "gender was decisive only [sic!] in the case of some forms of opposition activities. It's worth mentioning the activity of messengers and women who made apartments available. In the case of other underground activities, such as publishing, gender was of a secondary matter [sic!]"32. Surprisingly, he seems to approve only of those parts of Penn's findings (confirmed by other scholarly research and studies) which conform to traditionally gendered Polish women's roles (supportive, invisible), while he claims that the independent roles of a women-only team of editors (conceptual, significant) in Tygodnik Mazowsze were overestimated by Penn. He also omits important information that few men who joined the staff of Tygodnik Mazowsze did so in 1985, when the most decisive and risky period of martial law resistance was long gone ${ }^{33}$. Moreover, Olaszek disregards the importance of Tygodnik Mazowsze as the leading underground weekly of largest circulation, published for 7 years (1982-1989) which is confirmed for example by Encyklopedia Solidarności [The Encyclopedia of Solidarity] ${ }^{34}$. Paradoxically, while relying primarily on Penn's seminal research as well as the sources she indicates, Olaszek confronted with challenging material resists gender analysis of women's role in the underground history and largely perpetuates pervasive Polish gender stereotypes.

Notably, Olaszek is also one of numerous male editors of Encyklopedia Solidarności published by the same partially scholarly and partially political institution, IPN. Volumes I and II $(2010,2012)$ of this immense publication project contain biographical notes of almost 5000 Solidarity activists and surprisingly the search for the "Winiarska"/"Abramczyk" case, which is confirmed by, for example Penn and Pinior, does not render any results. Finally, among 22 editors of its four volumes, only one is a "token" woman editor (Mirosława Łątkowska) which seems to be below EU standards of gender equality. Such an approach may be also suggestive of an attempt to discredit gender history of resistance as a valuable form of interdisciplinary

30 Ibid., p. 292.

31 Ibid., p. 308.

32 Ibid.

33 S. Penn, "National Secret", p. 400.

34 “'Tygodnik Mazowsze', najważniejsze i najpopularniejsze pismo informacyjne podziemnej 'S' lat 80., wydawane w Warszawie 11 II 1982-12 IV 1989... Pismo założone przez grupę osób skupionych wokół Heleny Łuczywo (ps. Paweł Hofer)" [The Mazovian Weekly was the most important and the most popular information publication of the underground Solidarity, Published in Warsaw 11 Feb., 1982-12 June, 1989. A Weekly founded by the group of people in the circle of Helena Luczywo, pseudonym Paweł Hofer]. J. Szarek, “Tygodnik Mazowsze”, [in:] Encyklopedia Solidarności [The Encylopedia of Solidarity], http://www.encysol.pl/wiki/\%E2\%80\%9ETygodnik_Mazowsze\%E2\%80\%9D (access: 28.08.2016). 
academic inquiry, perhaps as a part of a larger anti-gender mobilization ${ }^{35}$, and poses a threat of appropriation of Solidarity's collective history by a well-funded, politically-charged, dominant institution, or a "Ministry of Memory".

\section{Is there no reliable gender history about Polish resistance?}

Unlike American historians such as Joan Wallach Scott, who theorized gender as "a useful category of historical analysis" in $1986^{36}$ after a decade of scholarship challenging the marginalization of women's history, the majority of Polish historians ${ }^{37}$ have been rather reluctant to address gender differences in their research ${ }^{38}$. In her article "Why Is There No Gender History in Poland?" (2010), Sylwia Kuźma-Markowska claims that "the weak position of women's history" and "virtual nonexistence of gender history" in Polish academia should be linked to "the dominance of political history, resistance to theory, a general lack of interdisciplinary approaches, reluctance to feminism, structural inflexibility and hierarchy that characterize Polish

35 About Polish anti-gender mobilization see A. Graff, "Report from the Gender Trenches: War Against 'Genderism' in Poland”, European Journal of Women's Studies 21, 2014, no. 4, pp. 431-442.

36 J. W. Scott, "Gender: A Useful Category of Historical Analysis", The American Historical Review 91, 1986, no. 5, pp. 1053-1075.

37 With several exceptions of gender and women's history studies published by Polish professional historians, e.g. Kobieta i... [Woman and...], ed. A. Żarnowska, A. Szwarc, Warszawa 1990-2006; E. Domańska, Historie niekonwencjonalne. Refleksja o przeszłości w nowej humanistyce [Unconventional Histories. Reflection on the Past in the New Humanities], Poznań 2006. D. Kałwa, Kobieta aktywna w Polsce międzywojennej. Dylematy środowisk kobiecych, Kraków 2001; eadem, "Historia kobiet versus studia gender - o potrzebie interdyscyplinarnego dialogu", [in:] Historia - dziś. Teoretyczne problemy wiedzy o przeszłości, ed. E. Domańska, R. Stobiecki, T. Wiślicz, Kraków 2014, pp. 115-126; M. Fidelis [of Polish descent, but working and publishing abroad], Women, Communism, and Industrialization in Postwar Poland, Cambridge 2010.

38 Polish discussions of gender and women's history are frequently authored by literary historians (M. Janion, op. cit.; A. Graff, Świat bez kobiet. Płeć w polskim życiu publicznym, Warszawa 2001; I. Iwasiów, "Płeć drugiego obiegu" [The Gender of the Second, Underground Circulation], [in:] Literatura II obiegu w Polsce w latach 1976-1989: Materialy konferencyjne [Literature of the Second Circulation. Conference Proceedings], ed. L. Laskowski, Koszalin 2006; eadem, "Gender dla średniozaawansowanych" [Gender for the Intermediate], Warszawa 2004; Granice. Polityczność prozy i dyskursu kobiet od 1989 roku [Boundaries. The Political in the Prose and Discourse of Women Since 1989], Szczecin 2013; A. Mrozik, "Wywołać z milczenia. Historia kobiet w PRL-u- Kobiety w historii PRL-u", Teksty Drugie 4, 2011, pp. 112-119; eadem, Akuszerki transformacji: Kobiety, literatura, władza po roku 1989 [Transformation Midwives: Women, Literature and Power], Warszawa 2012; Kobiety i historia. Od niewidzialności do sprawczości, ed. K. Błażowska, D. Korczyńska-Partyka, A. Wódkowska, Gdańsk 2015 or by sociologists (e.g. W. Grzebalska, Pteć Powstania Warszawskiego [The Gender of the Warsaw Uprising], Warszawa 2014; K. Dunin, "Miejsce z którego czytam" and "Pani Barbara" [The Standpoint I Am Reading From and Ms. Barbara], [in:] Czytając Polskę [Reading Poland], Warszawa 2004), or scholars of culture studies (e.g. K. Kułakowska, A. Łuksza, "Feminine Voice in Poland: The Case of Danuta Wałęsa”, Feminist Media Studies 15, 2015, no. 1, pp. 53-73). 
universities"39. She convincingly identifies numerous obstacles to studying gender history in Poland and publishing on it in the major Polish historical periodicals. She also suggests that two processes are required for the history of gender to develop in Poland: "accumulation of knowledge about women's history - that is, filling the gaps in historiography... [and] a greater interest in social and cultural history that would probably result in a more general opening of the whole discipline to theory" 40 .

Although Kuźma-Markowska mentions that several younger Polish scholars conduct research on social history or history of men and masculinity, she largely disregards interdisciplinary oral history projects and life writing on the gender history of women's resistance in the underground Solidarity. They have been conducted by both American and Polish scholars and journalists since the publication of Penn's seminal article "National Secret" (1994), in which she presented her preliminary conclusions based on 120 taped interviews, recorded in the first stage of her research since 1990, when eye-witness participants' memory of the events was fresh. Similarly, Kuźma-Markowska’s remark that there are few translations on women and gender history in Poland also does not apply to the transatlantic studies on Solidarity women active in the anti-communist resistance ${ }^{41}$. For example, the Polish translation of Penn's first article on the subject was published the same year as its American version (1994) in one of the first post-1989 Polish feminist scholarly journals, Petnym Głosem [In Full Voice] along with other texts documenting Solidarity women's resistance to the martial law repressions ${ }^{42}$. Interestingly, it was accompanied by a report by a Polish sociologist, Aldona Jawłowska, detained together with nearly 400 other anti-communist women activists in the Gołdap Camp for Women. Jawłowska's account featured also a collective (auto)ethnography documenting creative resistance of the interned women (e.g. performances "Wyjście z Gołdapi” [Leaving the Gołdap Women’s Camp]) ${ }^{43}$, "Oddaj głośnik" [Return the Loudspeaker], "Głodówka” [Hunger strike], as well as self-education, selection of satirical songs, and the stamp with an ironic logo of a witch riding her broomstick for women's illegal letters designed by one of the interned artists, Dorota Mulicka ${ }^{44}$.

39 S. Kuźma-Markowska, "Why There Is No Gender History in Poland?", Dialogue and Universalism 2010, no. 5/6, p. 9 .

40 Ibid., p. 17.

41 Ibid., p. 16.

42 S. Penn, “Tajemnica państwowa”, trans. A. Konstantowska, Pełnym Głosem 1994, no. 2. Jesień, pp. 3-16.

43 This protest performance the women internees staged before leaving the Gołdap Camp was filmed by American NBC journalists and included in the recent Polish documentary Solidarność wedtug kobiet [Solidarity According to Women], dir. M. Dzido, P. Śliwowski. Warszawa 2014.

44 A. Jawłowska, "Za szklaną ścianą. Raport o obozie odosobnienia dla kobiet w Gołdapi (fragmenty)", Pełnym Głosem 1994, no. 2. Jesień, pp. 17-32. “Gołdap women’s protest poetry", Pełnym Głosem 1994, no. 2. Jesień, pp. 33-37. See also: L. Wujec [in:] M. Sutowski, Wujec. Związki Przyjacielskie, Warszawa 2013, p. 209. 


\section{Transatlantic "archive fever" 1991-2005 — An oral history of Solidarity women's resistance}

The oral interview is an especially resonant form of remembering the recent individual as well as collective past by living witnesses and it has been used as a significant tool in many Western social sciences since the $1920 \mathrm{~s}^{45}$. Interviews in oral history projects have often focused on collecting the stories of groups which have been stigmatized because of e.g., their race, ethnicity, social status, gender, sexual orientation and silenced or marginalized in mainstream history. Oral history has become an especially important medium for preserving diverse traumatic memories such as those collected by the grassroots movement, the Holocaust Survivors Film Project, which was later deposited at Yale University in $1981^{46}$.

In the Central and Eastern European countries isolated from the West for decades by the Iron Curtain, experiencing the successive traumas of World War II followed by the communist regime and encountering obstacles in the access to reliable official documents, oral history, though with much delay in comparison to the Western countries, has proved an especially valuable methodology of accumulating the historical information in the form of recordings of testimonial narratives. In Poland, the concise underground reports about the tabooed histories of social protests and repressions focused primarily on providing counter-narratives to the propaganda of communist historiography in order to mobilize the collective memory into active resistance, rather than exploring ambiguities or conflicting views. Reading illegal publications of the second circulation about repressed Polish historical facts provided an antidote to totalitarian misinformation. However, the prolonged periods of collective traumas taking place on Polish territory caused by numerous political and military conflicts, extermination of large groups of people, and frequent, massive dislocations, changing of names and identities, authoritarian oppressions combined with the pervasive experience of vulnerability and shame of complicity and/or survival, resulted in multiple traumatic experiences which have not often been discussed publically. Therefore, oral history, which is "distinguished from other forms of interviews by its content and extent", because "oral history interviews seek an indepth account of personal experience and reflections, with sufficient time allowed for the narrators to give their story the fullness they desire" ${ }^{37}$, has proved a particularly important means of not only collecting personalized historical narratives, but also facilitating expressions of multiple, sometimes conflicting, views on the meanings of these events. In the process of constructing the oral history narratives, interviewees

45 Fortunoff Video Archive for Holocaust Testimony. See W. Webster, "Interviews", [in:] Encyclopedia of Life Writing: Autobiographical and Biographical Forms, ed. M. Jolly, London 2001, pp. 471-472.

46 Compare: Fortunoff Video Archive for Holocaust Testimonies. Yale University. New Haven 1979-1981, http://web.library.yale.edu/testimonies/about-- (access: 11.08.2016).

47 M. Marshall Clark, "Oral history" [in:] Encyclopedia of Life Writing, p. 678. 
could practice transcending ingrained (post)totalitarian attitudes and attempt articulating more complex views of their subjectivities. Although "the content of oral history interviews is grounded in reflections on the past as opposed to commentary on purely contemporary events" ${ }^{\prime \prime}$, through the intimate interaction and relationships based on trust involved in the eliciting and voicing of personal testimony, they can also have a democratizing effect of transcending the Cold War mental borders.

Since "the role of the interpreter is to enable and motivate the person being interviewed to tell stories about the past that amplify written accounts, or which document experiences that have not been written about or otherwise recorded" it required not only technical knowledge, but also sensitivity to obtain personal data about intertwined collective and individual Polish oppositionist's decisive moments of going underground, which as not only rational, but also affective outcomes must have been rather resistant to documentation for an American researcher. In addition, the post-1989 Polish rapid "shock therapy" of systemic transformation did not provide a convenient context for nuanced reflections on the recent past. Despite these initial impediments, Penn has managed to overcome the distrust and self-censorship of the former anti-communist women oppositionists and inaugurated what may be called a transatlantic "archive fever" 50 of oral history. During this period of an intense eliciting of the primary source documents in the form of interactive voice recordings ${ }^{51}$ with underground Solidarity women by both American and Polish researchers, numerous, valuable oral narratives were accumulated at a time when memories of resistance were still vivid before multiple experiences of women's post-1993 "bitter freedom", to use Elżbieta Matynia’s term, would eventually prevail. Significantly, these American and Polish oral historians and social activists cooperated to reach the biggest number of the central as well as regional women oppositionists. During the process of bearing witness, (re)constructing the events, contexts, as well as their considerations and interacting with the oral historian, eye-witness participants of discrimination and repressions were sometimes able to reclaim their agency over interpretation of their individual and collective lives and sometimes emerged more empowered from this process. Occasionally, the interpretations of the oral historian have been contested and resisted by the women oppositionists for various reasons often related to the post-communist political and social context.

Since most professional Polish historians have continued to distrust and marginalize oral history methodology ${ }^{52}$, employed for example in Penn's 1994 research

48 Ibid.

49 Ibid.

50 I borrow Derrida’s memorable title of his work Archive Fever: A Freudian Impression, Paris 1996.

51 Compare Ośrodek KARTA [KARTA Center] since 1989. In 2003 a separate department of the Archiwum Historii Mówionej [Oral History Archive] was established, http://www.audiohistoria.pl/ web/ (access: 28.05.2016).

52 Compare D. Kalwa, "Historia mówiona w krajach postkomunistycznych. Rekonesans", Kultura i historia 2010, no. 18, http://www.kulturaihistoria.umcs.lublin.pl/archives/1887 (access: 28.08.2016). 
publications, Ewa Kondratowicz, a Polish journalist and gender studies scholar, encouraged during the early 1996 interdisciplinary Polish gender studies program ${ }^{53}$ also conducted a parallel oral history project involving Polish women activists of the anti-communist underground. Her collection of twenty autobiographical interviews in Szminka na sztandarze. Kobiety Solidarności 1980-1989 (2001) [Lipstick on the Banner. Solidarity's Women, 1980-1989] confirmed Penn's thesis about the significance of women's resistance in the underground Solidarity. Unlike Penn's mediated, transnational study often paraphrasing, interpreting or quoting rather briefly the words of women eye-witness participants, Kondratowicz's project expanded Penn's representation of these women's language and reflected their diverse constructions of personal/collective narratives in long transcripts of extended interviews combining the methodology of gender studies with oral history ${ }^{54}$.

Penn also continued her oral history project based on a larger number of oral auto/biographical interviews with Polish women leaders and activists of the democratic opposition of the 1970s and 1980s from various regions and published her insights as well as carefully preserved women's differing interpretations of similar experiences in the more extended study, Podziemie Kobiet [Women's Underground] $(2003)^{55}$.

Paradoxically, it was an American woman researcher living in Berkeley, the site of an earlier important social movement, familiar with translations of male anticommunist dissidents' texts and fascinated by the Polish Noble laureate émigré poet, Czesław Miłosz lecturing on Slavic languages and literature at the University of California, who asked the research question "what did women do at that time?" [during martial law $]^{56}$. This gendered perspective made it possible for her to recognize the scope of Polish women's activism in the underground, especially when the most important male members of the resistance were interned, imprisoned, or had to remain in hiding, and enabled her to challenge the discourses circulating in both Poland and in Western countries foregrounding primarily male Solidarity oppositionists of the 1980s. In his review of Penn's later, award-winning study, Solidarity's Secret: Women Who Defeated Communism in Poland (2005), while recognizing and applauding the original focus of Penn's study, Kenney notes the advantage of such a transnational perspective "Ironically, the insiders who write social movement history often leave this stuff out; that has been true of most veterans of Solidarity" 57 .

53 See: Izabela Filipiak in the epigraph in E. Kondratowicz, Szminka na sztandarze. Kobiety Solidarności 1980-1989 (2011) [Lipstick on the Banner. Solidarity's Women 1980-1989], Warszawa 2001, p. 5.

54 Kondratowicz also authored Być jak narodowy sztandar. Kobiety i Solidarność [To Be Like a National Banner. Women and Solidarity], Warszawa 2013.

55 S. Penn, Podziemie kobiet [Women's Underground], trans. H. Jankowska, Warszawa 2003, was first published by a small publishing house, Rosner i Wspólnicy.

56 S. Penn, Solidarity's Secret, pp. 13, 16.

57 P. Kenney, "Review of Penn, S. Solidarity's Secret...". 
However, when focusing on another advantage of women's history, Kenney seems to rely on the gender stereotypes of women activists' testimony: "when research focuses on women in social movements - one learns an enormous amount about the praxis of opposition... the experience of Solidarity, behind manifestos and essays" 58 . At the same time, he also acknowledges the unique depth of Penn's standpoint and the discussion of her extensive material: "But Penn takes us much further. We learn where meetings took place... how the newspaper was assembled... about the half-life of safehouses, and about life in them" ${ }^{\text {59 }}$. The second asset of Penn's study, according to Kenney, is also connected with her feminist perspective which examines women's social roles and their use of their bodies to conceal their resistance work, for instance as artificial pregnancy used as camouflage for transporting illegal papers. Ironically, Kenney does not consider the serious challenges that real (not only pretended) motherhood posed to those women active in the underground resistance. Some of them were single mothers at the time (e.g., editors of Tygodnik Mazowsze - J. Szczęsna, A. Dodziuk, Z. Bydleńska and an activist from the Gdańsk shipyard, A. Pieńkowska). Others involved in the oppositionists' marriages, such as Barabara Labuda, Ludwika Wujec, Helena Łuczywo, were imprisoned or interned at the same time as their husbands and fathers of their young children (often also their close relatives), which deprived their children of both parents and threatened them with the prospect of being placed in state orphanages. Real motherhood also posed challenges to women such as Ewa Kubasiewicz-Houée ${ }^{60}$, the oppositionist with the longest prison sentence (10 years), whose young adult son was also imprisoned because of his mother's activism in the resistance during martial law and she faced a choice between resistance and her parenting responsibility, choosing the former, since she believed her freedom-fighting was going to benefit her son more in the longer perspective ${ }^{61}$.

Yet, while appreciating the scope of Penn's original research, Kenney still regrets that three decades after Solidarity's inception there is no comprehensive history of the whole social movement of Solidarity as "a research monograph... to portray the birth, life, and afterlife of this immensely important actor in European history"62. As if dismissing the interdisciplinary and polyphonic structure of Penn's collaborative

58 Ibid.

59 Ibid.

${ }^{60}$ Compare E. Kubasiewicz-Houée's short memoir, Bez prawa do powrotu [Without the Right to Return], Wrocław 2005.

${ }^{61}$ See E. Klimek-Dominiak, "80 milionów i 80 tysięcy" [ 80 millions and 80 thousands], Zadra. Pismo feministyczne 64-65, 2015, no. 3-4, pp. 66-67 for the discussion of how Polish female and male Solidarity oppositionists were differently engendered in two films (Solidarność wedlug kobiet [Solidarity According to Women] dir. M. Dzido, P. Śliwowski, Warszawa 2014, and 80 Milionów [80 Millions] dir. W. Krzystek, 2011) and how they reacted to imprisonments or despair. For example, Piotr Bednarz's suicide attempt in prison was followed by unsuccessful surgery and a life-threatening condition, was transported and rescued owing to the woman oppositionist's initiative, Elżbieta Sienkiewicz.

${ }^{62}$ P. Kenney, "Review of Penn, S. Solidarity's Secret...". 
work, Kenney seems to yearn for a more totalizing "grand narrative" of Solidarity. In addition, despite the fact that Penn included an English language and Polish bibliography of both academic, archival, and media sources on Polish history, Kenney, the American author, who also published on Solidarity and the role of gender in resistance following Penn's original research article "National Secret" $(1994)^{63}$, suggests that her later study is just "a collective biography of seven women (a number of other play supporting roles in the narrative) and their efforts to save Solidarity in the years after martial law was declared in $1981^{\prime \prime 64}$. Thus, in his evaluation the American historian seems to disregard the hybrid, multivocal, inclusive form of Penn's auto/biographical project, combining extensive oral interviews with many eye-witness participants and her cultural analysis of Polish gender mythology in the history of Polish freedom-fighting and women's traditional role as self-sacrificing and family-centered "Polish Mothers" 65 .

Penn's transatlantic perspective comparing the post-1968 social protest movements in the U.S. and waves of Polish political and social upheavals between 19681989 , noting both differences and similarities, is a valuable contribution to research on gendering of activism as represented in personalized accounts of anti-totalitarian oppositionists. In particular, Penn's analogy between Rosa Parks and Anna Walentynowicz, who both have been longtime women activists of civil rights and free trade unions and Solidarity respectively, can explain "how women are silenced within a single issue movement that is bigger and more urgent than gender equality; that is how sex discrimination becomes an unacknowledged offence within a social movement"66. Both women activists, who catalyzed events leading to massive protests, have become obliterated and they are remembered primarily as symbolic figures rather than political agents. In addition to the gendered hierarchy of social movements, Penn also considers the influence of other social aspects such as ethnicity, class and age-based factors as they affected both American and Polish post-1968 dissent activism. In this way, the American oral historian globalizes the Polish student protests and, as if symbolically removing the Iron Curtain divisions, she integrates them into the larger transnational history of activism:

In the broadest terms, Poland's ' $68 \mathrm{ers}$ followed a course parallel to that of the sixties generation in the West, displaying an impressive capacity to ... utterly disrupt the status quo... Both groups shed their political illusions, found their rage, and endured the ensuing psychic implosion. Both groups searched for identity and community and rejected 'the system.' And both made history. Even though East-West exchanges were few and far between, that 'sixties' spirit-the consciousness, the critique, the impact, and the aura - transcended borders ${ }^{67}$.

63 P. Kenney, “The Gender of Resistance in Communist Poland", pp. 399-425.

64 Ibid.

65 S. Penn, Solidarity's Secret, esp. “Our Romantic Model: Myth Literature, and Women's Place", pp. 241-261.

66 Ibid., p. 64.

${ }^{67}$ Ibid., p. 112. 
She also notes differences between them. While tracing the genealogy of major women oppositionists of the underground Solidarity who "belonged to Poland's sixties generation - the " $68 \mathrm{ers"}{ }^{68}$ she specifies that their formative experiences included the brutally suppressed student protests. She shows how the communists' manipulation through anti-Semitic campaigns, which provoked ethnic conflicts and political purges, constituted their initiation into the painful, eye-opening, encounters with totalitarian practices and led many young Polish people to activism in the pre-Solidarity opposition of KOR. Another disparity between the Polish group of future Solidarity oppositionists and the first American post-war generation of dissenters concerns the ages when they become involved. Among American students, college usually marked the beginning of non-conformism, while in Poland the social and discussions about resistance and political awakening frequently occurred in high school. Moreover, Polish dissenters "by American standards at the time... were virtuous, serious youth... Instead of taking illicit drugs, books were the drugs of choice, especially the prohibita, books that the state had censored" 69 . As a self-identifying Jewish American, Penn sensitively considers layers of women oppositionists' often unacknowledged complex ethnic identities, paying special attention to the ambiguous positioning of the several women oppositionists, whose Jewish-born parents sought post-Holocaust security by working within the communist system.

However, as collaborative, mediated (often translated ${ }^{70}$ processes, oral interviews are "hybrid genres combining oral testimonies usually offered in private exchanges and written narratives often focused on addressing wider public questions and concerns", which can also reveal imbalances of power between the narrators' agency over their stories and the oral historians' interpretations ${ }^{71}$. This is a sensitive issue, especially in transnational interaction, and it involves verification of the accuracy of both the oral narrative and how it is contextualized or rendered in the written form, which sometimes involves translation. Thus, the process of validation of historical evidence by other sources is usually necessary and sometimes may evoke considerable resistance from various sources.

68 Ibid.

69 Ibid., p. 119.

70 Compare Penn's description of her methodology, ibid., pp. 19-27.

71 Compare: W. Webster, "Interviews", [in:] Encyclopedia of Life Writing: Autobiographical and Biographical Forms, ed. M. Jolly, London 2001, pp. 471-472. 